\title{
Internationalization Propensity of Small Scale Enterprises in Kampala, Uganda
}

\author{
Olutayo K. Osunsan ${ }^{1}$, Susan Busingye ${ }^{2}$, Rachael Ritah Mpora ${ }^{3}$, \\ Michael Timbirimu ${ }^{4}$ \\ ${ }^{1}$ Lecturer (Corresponding Author), Department Of Business \& Management, College Of Economics \& \\ Management, Kampala International University, Uganda. \\ ${ }^{2}$ Lecturer, Department Of Human Resource Management \& Procurement, College Of Economics \& \\ Management, Kampala International University, Uganda \\ ${ }^{3}$ Lecturer, Department Of Human Resource Management \& Procurement, College Of Economics \& \\ Management, Kampala International University, Uganda. \\ ${ }^{4}$ Lecturer, Department Of Accounting \& Finance, College Of Economics \& Management, Kampala \\ International University, Uganda.
}

\begin{abstract}
This paper unequivocally focuses on the question of "how" (mode of entry), rather than "when" (timing of market entry) or "where" (location) to enter a foreign market. Therefore sought to explore how (mode of entry) and the levels of internationalization among selected small scale enterprises in Kampala, Uganda. In so doing it identifies the propensity of small scale enterprises to internationalize in the context of Kampala, Uganda. Data was collected through self-administered questionnaire and a total of 409 responds were received. The findings revealed that the mode of entry/internationalization is dominantly sporadic exporting and internationalization levels as a whole is very low among the small businesses considered in the study. A peripheral finding in this study was that most of the internationalization efforts were focused on neighboring countries (location). The recommendation was made that small businesses should be encouraged to establish more networks in foreign markets to instill more confidence and willingness to internationalize on a larger scale.
\end{abstract}

Keywords: Entry Mode, Internationalization, Exporting, Small Business, Kampala, Uganda. JEL: M10, M16, L21, L26

\section{Introduction}

The luxury of growing into a big business and then internationalizing has not always been afforded to contemporary small businesses due to merging global markets and technologies that eliminate the once protective barrier of distance (Sapienza, Autio, \& Zahra, 2003; MFPED, 2008). Home country markets have opened to foreign companies and small enterprises face the competitive challenge of both domestic and overseas rivals and a response is for small businesses to enter foreign markets, provoked by push factors which arise from areas of difficulty in the domestic markets, where a targeted overseas market may offer a solution (LloydReason, 2003; MFPED, 2008). Tesfayohannes (2012) however pointed out in the African context that; "[small business owners]... have continued confronting formidable challenges. This is due to the new reality marked by increasing international business interactions and socio-economic and technological interdependency affecting all developed and developing economies around the globe. This in turn has brought enormous intricacies and complexities in conducting business both domestically and internationally. The impact of massive technological discoveries and innovations is now felt everywhere including in Africa with the ever expanding outreach. Unfortunately, entrepreneurs in African nations are insufficiently aware of this phenomenon. Many of them have continued to devote their full time and energy in a limited local domain and static business styles which might not warrant them sustainability and growth" (p. 1).

In Uganda there are also several definitions of a small business. Small business is defined as an enterprise employing a minimum of 5 peoples and a maximum of 50 people, with annual sales turnover of maximum 360 million Uganda shillings and total assets of maximum 360 million Uganda shillings (MFPED, 2008). The Uganda National Bureau of Statistics (UBOS, 2011) on the other hand categorized small businesses as those that generate an annual turnover of between 5 and 10 million shillings irrespective of the number of employees. A common point of agreement is the fact that small businesses are major engines for economic development, through employment and tax contribution among other factors (Osunsan, 2015; MFPED, 2008).

According to Singh, Pathak \& Naz (2010) internationalization is a term that has been used loosely in the literature and is not only limited to exporting but also includes trade, cross-border clustering, collaborative partnerships, alliances, branches, subsidiaries, and joint ventures that extend beyond the home country 
environment. The internationalization of businesses has in the past been considered an exclusive area for big and resourceful companies. The evolution of Information Communication Technology, and globalization of markets, has changed this believe, more small businesses are becoming active in the international markets. Tesfayohannes (2012) suggested that; “...African entrepreneurs should actively participate in international business interactions in order to run a viable and sustainable business" (p. 3).

Internationalization is believed to be an integral component to business success (Zain $\& \mathrm{Ng}, 2006$ ), more so in relation to survival, longevity, market expansion, access to new technology, access to capital, access to expertise and the gradual establishment as a key player in regional markets and economies (Patel \& D'souza, 2009; Peng \& Delios, 2006). Internationalization among small businesses in the developing world and Africa in particular remains a challenge and a sparsely explored area (Tesfayohannes, 2012; Rutashobya \& Jaensson, 2004). In fact Rutashobya \& Jaensson, 2004 pointed out that; "The internationalization of firms has been studied extensively. However the internationalization of small firms, especially from a developing country perspective, has received little attention in academic inquiry."(p. 2). Matenge (2011) also pointed out that contemporary theories and literature on small business internationalization are solely influenced by those of developed nations, echoing the outcry of limited literature on small business internationalization in the African context (Rutashobya \& Jaensson, 2004). In response to this sentiment, this study therefore sought to investigate how (mode of entry) and the levels of internationalization among selected small scale enterprises in Kampala, Uganda.

The paper is structured as followed: section two consists of the reviewed literature; section three consists of the methodology; section four displays and explains the key findings; section five provides the conclusions and recommendations.

\subsection{Internationalization}

\section{Literature Review}

Johanson and Vahlne (1977) define internationalization as a process of incremental commitment of resources into foreign markets. Welch and Luostarinen (1988) concurred by defining internationalization as the process in which firms increase their involvements in international operations. Similiarly Wu and Zhao (2007) claimed that internationalization is the product of a series of incremental decisions. Chelliah, Sulaiman and Yusoff (2010) defined internationalization as: "the extent to which a firm is involved in international business. It includes exporting, the presence of foreign subsidiaries, shares ownership by foreigners and the appointment of foreigners in the organizational structure" (p.29). According to Johanson \& Vahlne (1977) firms begin the internationalization process in markets that have less psychic distance, which are factors such as differences in language, culture, political systems, values, believe system, and others. It is assumed that more or higher psychic distance can disturb the flow of information between the firm and the foreign market (Johanson \& Wiedersheim-Paul 1975), thus inhibiting market knowledge which in turn hinders market commitment. The foreign operation is initiated by using exports and gradually moving to more intensive and demanding operation modes of entry(overseas sales subsidiaries, etc), thus escalating the commitment in terms of risks and resources poured into internationalizing the business (Johanson \& Wiedersheim-Paul 1975; Johanson \& Vahlne, 1977; Ahmed, 2010).

International business has in the past been perceived as an exclusive area for large and resourceful companies (Dunning, 1997). Literature confirms that internationalization research initially focused on the activities of the corporations before evolving attention to a certain extent to the behavior of the small and medium sized enterprises (Coviello \& Munro, 1995). Smaller businesses are embracing international activities and are displaying characteristics not previously seen before (McAuley, 1999; Cummins, Gilmore, Carson \& O'Donnell, 2000) due to the changing landscape of business and technology. Small businesses were initially limited by internal factors, such as their size, lack of financial resources, poor management and marketing skills, lack of previous internationalization experiences and knowledge, as well as crucial knowledge on foreign market information. They are also burdened by external limitations such as financing problems in form of access to cheap capital, technical barriers such as lack of innovativeness, and complications relating to the internationalization processes and procedures (Rutashobya \& Jaensson, 2004). But the advancements in information, communication and transportation technology, and globalization of markets, have changed this. More and more small businesses are engaging internationalization and are succeeding, especially in the western world (Wright, Westhead, \& Ucbasaran, 2007; Bell, Crick, \& Young, 2004; Cummins et al., 2000). There is now increasing evidence signifying that small businesses may have to rely on networks and relationships to overcome their size limitation to enable successful internationalization (Matenge, 2011; Zizah, 2010; Johanson \& Vahlne, 2009). These networks act as a basis of competitive advantage for small businesses (Wright, et al 2007). This same approach could usher the way for small businesses in developing nations such as in the context of Uganda and Africa as a whole. 


\subsection{Mode of Entry}

The choice of entry mode plays a significant role for a business in terms of success or failure and effects all the future decision and operations of the business in the new marketplace (Durmaz and Taşdemir, 2014). According to Root (1994), a foreign market entry mode is "an institutional arrangement that makes possible the entry of a company's products, technology, human skills, management or other resources into a foreign country" (p. 5). Root (1994) farther categorized modes of entry into foreign markets as: (i) export modes and that comprises indirect and direct exporting, direct agent and direct branch subsidiary and other; (ii) contractual entry modes such as licensing, franchising, technical agreements, service contracts, management contracts, construction/turnkey contracts, co-production contracts and other; and (iii) investment entry mode which includes sole ventures and joint ventures in forms of new establishment and acquisitions. Wright, et al (2007) identified the elements of International modes of entry, pointing out that firms can internationalize through a various entry modes such as exports, alliances, joint ventures, FDI or acquisition (Dana and Wright, 2004), with varying the modes of foreign entry differing based on degrees of resource commitment, risk potential, the possibility of returns and managerial control/autonomy.

Rowden (2001) pointed out with reference to Dollinger (1995) that the internationalization of small businesses can be a staged process which progresses through: (i) passive exporting, (ii) export management, (iii) export department, (iv) sales branch, (v) production abroad, and finally (vi) The transnational. Similar to Rowden (2001), Forsman, et al (2002), Ural and Acaravci (2006) and Johanson \& Vahlne (1977) confirmed that sporadic exporting is the initial level of the internationalization process and FDI at the extreme end. The same point is made by Abdullah \& Zain (2011), who assert that exporting was the most used mode of entry (almost 75\% utilized). In fact Abdullah and Zain (2011) corroborated the mode of entry into foreign market, point out that exporting is the most accepted mode while less volumes of businesses use franchising, joint venture or wholly own subsidiary.

\subsubsection{Exporting}

Export is the most common mode for initial entry into international markets (Hollensen, 2007) due to the low risk involved and the limited knowledge of foreign market needed (Thompson, Strickland and Gamle, 2010). Baker (2003) defined exporting as the process of sending or carrying of the goods abroad, especially for trade and sales. With Export as an entry mode, a business's products are manufactured in the domestic market or a third country, and then transferred to the host market (Driscoll and Paliwoda, 1997) by means of indirect or direct exporting (Kotabe and Helsen, 2010). An initial aspect of full scale exporting is sporadic exporting (Johanson \& Vahlne (1977), where exporting is engaged at inconsistent and irregular basis. According to Hauck (2010) the behavior (sporadic exporting) is an indicator of their priority and the low propensity to change over time. Exporting is normally the common option for most small businesses as a way to sell their goods in foreign markets (Kotabe and Helsen, 2010). Bradley (2005) argued that exporting can be a part of continuum of increase commitment to internationalization.

\subsubsection{Licensing}

Licensing is a contractual deal where the business (the licensor) offers some proprietary assets to foreign business (the licensee) in exchange for royalty fees (Kotabe and Helsen, 2010). A licensor may give exclusive or non-exclusive rights to a particular licensee (Aulakh, Jiang and Pan, 2010). Licensing offers more control than exporting since grants a foreign entity the right to produce and sell the business's product in return for a royalty fee on every unit that the foreign entity sells (Sooreea, Sharma and Luong, 2012). Bradley (2005) pointed out that forms of licensing can involve one or a combination of brand name, operations expertise, manufacturing process technology, access to a patents and trade secrets.

\subsubsection{Franchise}

A franchise agreement is a contractual arrangement between two independent businesses, whereby the franchisee pays the franchisor for the right to sell the franchisor's product and/or the right to use the franchisor's trademark at a specific location and for duration of time (Lafontaine, 1993). Bradley (2005) asserted that franchising is a derivative of licensing where the business format is licenses instead of the technology. Under the franchising mode, the franchiser normally leases its brand name, and provides marketing support, technical advice and training, to the franchisee (Erramilli, Agarwal, and Dev, 2002).

\subsubsection{Contract manufacturing}

In contract manufacturing, the businesses product is manufactured in the foreign market by local producer under contract with the business (Lambin, 2007). It is a form of outsourcing. According to Root (1994) this entry mode is a cross between licensing and investment entry. The manufacturer's responsibility is limited to production. On completion, products are handed over to the international company which usually 
assumes the marketing responsibilities for sales, promotion and distribution (Akkaya, 2002). Contract manufacturing offers considerable flexibility, for example if the business is dissatisfied with product quality or reliability of delivery it can shift to another manufacturer.

\subsubsection{Management contracting}

Management contracting is where one business (contractor) supplies management know-how to another (business) that provides the capital and takes care of the operating value chain functions in the foreign country (Hollensen,2007). Management contracts are focused in particular industries such as hotels, transportation, agriculture, public utilities and mining and mineral. Usually these contracts do not give them the right to take decisions on new capital investment, policy changes, assume long-term debt or alter ownership arrangement (Root, 1994).

\subsubsection{Partnerships and Strategic Alliances}

A strategic alliance involves a contractual agreement between two or more enterprises stipulating that the involved parties will cooperate in a certain way for a certain time to achieve a common purpose. Partners are especially valuable if they have a recognized, reputable brand name in the country or have existing relationships with customers that the firm might want to access. Joint venture is an example of a specific type of partnership alliance (Thompson, Strickland and Gamle, 2010). The average lifespan for alliances is only about seven years, and in the case of joint ventures, nearly 80 per cent of joint ventures ultimately end in a sale by one of the partners (Hollensen, 2007).

\subsubsection{Joint Ventures}

Joint ventures (JVs) are an investment entry mode. Investment entry modes has many names like sole venture (Root 1994), Foreign Direct Investment (FDI) (Chung \& Enderwick, 2001), solely owned subsidiary (Agarwal \& Ramaswami, 1992) and wholly owned subsidiary (Chung \& Enderwick, 2001). Joint ventures have become an important element of many firms' international strategy (Durmaz and Taşdemir, 2014). Joint ventures are business agreements where by two or more owners (businesses) create a separate entity. The joint venture can be a partnership or a closely held corporation, or can issue corporate securities in its own right (Harrigan, 1988). Joint ventures not only share risks, but also decrease the total investment. It is an alternative to whollyowned subsidiaries (Durmaz and Taşdemir, 2014).

\subsubsection{Wholly Owned Subsidiary}

Recent trends in deregulation in international capital markets have given acquisition new importance as a mode for Foreign Direct Investment (Cheng, 2006). Acquisition is typically presented as the alternative to Greenfield. Acquisition is defined as the purchase of the stocks of an established firm in the host country by another firm headquartered outside the country, alone or with one or more partners, in an amount sufficient to confer control (Durmaz and Taşdemir, 2014). While Greenfield entry into a foreign market involves the establishment of a new affiliate in a host country by another firm headquartered outside the country, alone or with one or more partners (Cheng, 2006).

Several scholars (Doole \& Lowe, 2004; Sim \& Pandian, 2007) pointed out that no aspect of internationalization be it sporadic exporting or foreign direct investment (or wholly owned subsidiary) is possible without the establishment of a network of some sort with at least a player or players in the foreign market or markets.

\subsection{Levels of Internationalization}

Measuring the levels and degree of internationalization has various and diverse views and approaches. In fact Ietto-Gillies (2009) concluded that "the degree of internationalization is a multifaceted concept and therefore there is no unique, 'correct' index: indices may or may not be appropriate to the task we assign them" (p. 2). Small businesses internationalization has been measured through diverse means which include networking with foreign firms, accessing foreign countries through trade fairs, exporters and publications; as well as entering into joint ventures, licensing arrangements and subcontracting (Pollard, 2001). Sullivan (1994) argued basing on the precepts of the measurement theory that multiple item measures should be used in measuring internationalization instead of single units. Manolova, Brush, Edelman \& Greene (2002), for example, measured internationalization on the basis of firm activities such as import, direct export, export through an intermediary, solo venture direct investment, joint venture direct investment, licensing of a product or service, contracting and, franchise. A similar approach was used by Ogbuehi \& Longfellow (1994). Contractor, Kundu and, Chin (2003) measured internationalization using the eigenvector-weighted sum of FSTS (foreign sales/total sales), FETE (number of foreign employees/number of total employees) and FOTO (number of foreign offices/number of total offices). Jankowska (2011) reviewed indicators for measuring 
internationalization in terms of: (i) internationalization of production and sales, (ii) internationalization of factors of production and (iii) the degree of connections with foreign capital markets.

\section{Methodology}

This study adopts a quantitative approach; since some literature discusses that a quantitative method is better because it is more "scientific" (Ghauri and Grönhaug, 2005). A descriptive study as it was undertaken in order to describe the phenomenon of internationalization among small business in Kampala, and is focused more on the 'how' question (Masum and Fernandez, 2008). Amin (2003) argued that for the sake of practicality and manageability, a researcher should carry out the research on a portion of the target population. The unit of analysis in this study is the individual small businesses and the owner managers are the unit of enquiry as suggested by Vida, Reardon \& Fairhurst (2000). The target population in this study involved 360,000 legally registered small businesses in Kampala. The Slovin's formula was thus given as by Serakan (1992) cited in Dionco-Adetayo (2011): $\mathrm{n}=\mathrm{N} / 1+\mathrm{N}(\mathrm{e})^{2}$. Where $n$ is the sample size, $N$ is the population size, and $e$ is the margin of error. Applying 5\% error margin Slovin's formula recommended a minimum sample size of 400.600 questionnaire where sent out, using purposive sampling to identify the respondents on the basis of (i) exists in the administrative division of Kampala, (ii) legally registered, (iii)employs more than 5 and not more than 50 people; and 409 questions where retrieved. This study adopted Manolova, et al. (2002) approach to measuring internationalization. That is based on firm activities such as sporadic export, export, direct investment, joint venture, licensing, contracting, and franchise among others. This study used a Likert-type scale as used by Ciszewska- Mlinaric \& Mlinaric (2010). The scales ranged from a minimum of one (strongly disagree; very low) to a maximum of four (strongly agree; high). Though some respondent were engaged in informal interviews in order to get clarity on the 'how', this has been recommended by scholars such as Rocco, Bliss, Gallagher \& Perez-Prado (2003). This study however remains qualitative in nature. The data was presented and analyzed using graphs, means, standard deviations, t statistics and ranks. Interpretation is based on: 3.26-4.00 High level, 2.51-3.25 - Moderate, 1.76-2.50 -Low, and 1.00-1.75 -Very Low.

\subsection{Demographic Characteristics}

\section{Findings}

63.1 percent of the 409 small scale enterprises that were considered in this study were male owned and 36.9 percent were female; most businesses have 5 to 9 employees (43.5\%), followed by those employing 10 to 19 , accounting for 38.1 percent; the study considered over 14 industry sectors, 'others' industry/sector types consisting of cleaning services, Construction, Insurance, Banking, Agribusiness, Textile, Real Estate, Entertainment, Security and petroleum accounted for $14.9 \%$, followed by the Beauty/Cosmetics which made up $14.4 \%$, the Printing/Publishing and Office Supplies sector accounted for the least represented respondents at $2.7 \%$; most of the businesses were 10 years old or less (314) and $90.7 \%$ of the businesses have existed for less than 16 years.

\subsection{Mode of Entry adopted}

Figure 1 confirms that out of the 409 small scale enterprises, a majority of $312(76.3 \%)$ have engaged sporadic exporting as a means of internationalization. With the exception to sporadic exporting all the other modes of entry were below $22 \%$. Exporting was adopted by $88(21.5 \%)$ of the businesses, while the third most common mode adopted was Partnership which accounted for $21.0 \%$. The least adopted mode of entry was Foreign Direct Investment (FDI) which accounted for 59 (14.4\%) of business sampled.

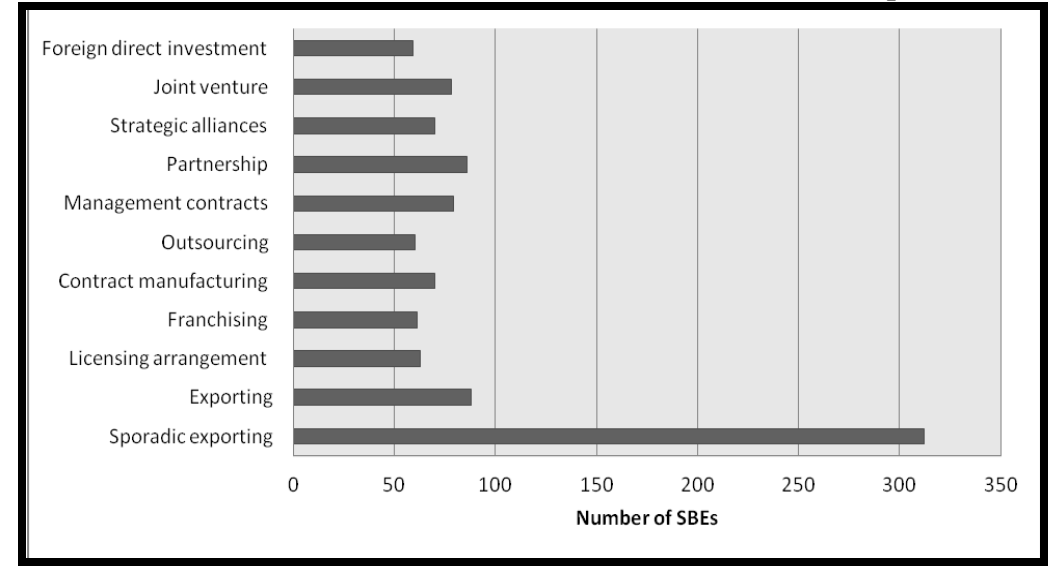

Figure 1: Mode of entry/Internationalization adopted by small businesses 
Further scrutiny, through informal interviews confirmed that most of the sporadic exporting was to neighboring countries such as Kenya, Tanzania, South Sudan and Rwanda. This confirms the claim made by Johanson and Vahlne (1977) and other scholars that businesses tend to expand into markets with closer/low psychic distance. In the case of this study language (English and Swahili), proximity and similarity in culture were a factor. In a few cases the respondents pointed out that they had ancestry links to some of the mentioned countries.

\subsection{Level of Internationalization}

Table 1: Levels of Internationalization among Small Scale Enterprises

\begin{tabular}{|l|l|l|l|l|l|}
\hline $\begin{array}{l}\text { Modes of Entry/ } \\
\text { Internationalization }\end{array}$ & Mean & $\begin{array}{l}\text { Std. } \\
\text { Deviation }\end{array}$ & t-value & Interpretation & Rank \\
\hline Sporadic exporting & $3.30^{* * *}$ & 1.12 & 2.95 & High & 1 \\
\hline Exporting & 1.61 & 1.09 & 1.48 & Very Low & 3 \\
\hline Licensing arrangement & $1.47^{*}$ & 0.85 & 1.74 & Very Low & 8 \\
\hline Franchising & $1.43^{*}$ & 0.85 & 1.68 & Very Low & 11 \\
\hline Contract manufacturing & 1.52 & 0.95 & 1.61 & Very Low & 5.5 \\
\hline Outsourcing & $1.45^{*}$ & 0.86 & 1.69 & Very Low & 9.5 \\
\hline Management contracts & 1.54 & 0.94 & 1.63 & Very Low & 4 \\
\hline Partnership & 1.63 & 1.00 & 1.62 & Very Low & 2 \\
\hline Strategic alliances & $1.51^{*}$ & 0.89 & 1.70 & Very Low & 7 \\
\hline Joint venture & $1.52^{*}$ & 0.92 & 1.66 & Very Low & 5.5 \\
\hline Foreign direct investment & $1.45^{*}$ & 0.85 & 1.70 & Very Low & 9.5 \\
\hline Total: & $\mathbf{1 . 6 8}$ & $\mathbf{0 . 9 4}$ & $\mathbf{1 . 7 9}$ & Very Low & \\
\hline
\end{tabular}

$* * *$ significant at the $0.01 ; *$ significant at the 0.10

As reflected in table 1 , the level of internationalization is very low $(\mathrm{M}=1.68 ; \mathrm{t}=1.79)$ among small scale enterprises in Kampala, Uganda. This same finding is also confirmed by figure 1 in terms of frequencies. In both cases sporadic exporting is high (table 1: $\mathrm{M}=3.30 ; \mathrm{t}=2.95$ ). I can be safe to say in this study, the more dominant aspect/mode of entry/internationalization used by the small businesses is sporadic exporting which might reveal that internationalization is at its very early stages among the businesses (Bradley, 2005). It farther confirms the lesser inclination by the businesses considered for this study to commit more extensively to higher levels of internationalization, such as foreign direct investment. This confirms the claims that small businesses do not have the resources, experience or the expertise to adopt more extensive and resource intense internationalization modes such as wholly owned subsidies or foreign direct investment (Thompson, et al, 2010; Kotabe and Helsen, 2010). This confirms and is in agreement with researcher who emphasis the use of export as a major means and initial mode of internationalization among businesses and more so small businesses (Thompson, et al, 2010; Kotabe and Helsen, 2010; Hollensen, 2007). On the basis of Bradley's (2005) argument this could suggest that sporadic exporting can be a part of continuum of increase commitment to internationalization

\section{Conclusions And Recommendation}

This study sought to investigate how (mode of entry) and the levels of internationalization among selected small scale enterprises in Kampala, Uganda. On the basis of the findings, the following conclusions can be made: (i) several mode of entries are adopted by small businesses considered in this study, but the most dominant mode is sporadic exporting; (ii) though internationalization is evident in the context of small businesses in Kampala, Uganda the levels is very low; and (iii) the engagement of internationalization at both very low levels and initial entry mode (sporadic export) could suggest future increase in internationalization levels and embrace of more diverse modes of entry by the small businesses. On the peripheral the conclusion can also be drawn that psychic distance is a major determinant of internationalization.

The recommendation can therefore be made that small businesses need to establish more networks in foreign markets, starting with those with low psychic distance such as neighboring countries. This can be done through government diplomacy and trade show initiatives that exposes small business owner-managers to foreign businesses and networks. These networks can act as a means to get more knowledge and exposure to foreign markets that will enable small businesses commit more resources to internationalization.

\section{Reference}

[1]. Abdullah, N.A.H. \& Zain, S. N. (2011). The internationalization theory and Malaysian small medium enterprises (SMEs). International Journal of Trade, Economics and Finance, 2 (4), 318322.

[2]. Agarwal, S. and Ramaswami, S. N. (1992). Choice of Foreign Market Entry Mode: Impact of Ownership, Location and Internalization Factors. Journal of International Business Strategy. 23(1), 1-27.

[3]. Akkaya M. Fatih, (2002). Global Marketing Strategies Republic of Turkey Ministry of Economy. Retrieved from http://www.ekonomi.gov.tr/upload/BF09AE98-D8D3-8566 4520B0D124E5614D/Fatih_Akkaya.pdf

[4]. Amin, M.E. (2003). Social Science Research: Conception, Methodology and Analysis. Kampala: Makarere University Printery. 
[5]. Aulakh Preet S., Jiang Marshall S. and Pan Yigang (2010). International Technology Licensing: Monopoly Rents, Transaction Costs And Exclusive Rights Journal of International Business Studies, Vol. 41, No. 4 (May 2010), pp. 587-605

[6]. Baker, M. J. (2003). The Marketing Book, Butterworth-Heinemann An imprint of Elsevier Science Linacre House, Jordan Hill, Oxford OX2 8DP 200 Wheeler Road, Burlington MA 01803

[7]. Bell, J., Crick, D. \& Young, S. (2004). Small firm internationalization and business strategy: an exploratory study of 'knowledge intensive' and 'traditional' manufacturing firms in the U.K. International Small Business Journal, 22(1), 23-56.

[8]. Bradley, F. (2005) International Marketing Strategy 8th edition Prentice Hall, London

[9]. Chelliah, S., Sulaiman, M. \& Yusoff, Y. M. (2010). Internationalization and Performance: Small and Medium Enterprises (SMEs) in Malaysia. International Journal of Business and Management, 5(6), 27-37.

[10]. Cheng, Yung-Ming (2006). Determinants of FDI Mode Choice: Acquisition, Brownfield, and Greenfield Entry in Foreign Markets, Canadian Journal of Administrative Sciences 23 (3), pp. 202-220

[11]. Chung, H. \& Enderwick, P. (2001) "Investigation of Market Entry Strategy Selection: Exporting vs. Foreign Direct Investment Modes-A Home-host Country Scenario", Journal of Management, 18, 443-460.

[12]. Ciszewska-Mlinaric, M. \& Mlinaric, F. (2010) Small Firms in a Small Country: Managerial Factors, Internationalization and Performance of Slovenian SMEs. Managing Global Transitions, 8 (3), 239-259.

[13]. Contractor, F.J, Kundu, S.K., \& Chin, C.H. (2003). A three stage theory of international expansion: The link between multinationality and performance in the service sector. Journal of International Business Studies, 34, 5-18.

[14]. Coviello, N.E. \& Munro, H.J. (1995). Growing the entrepreneurial firm \pm networking international market development. European Journal of Marketing, 29(7), 49-61.

[15]. Cummins, D., Gilmore, A., Carson, D. \& O’Donnell, A. (2000). Innovative marketing in SMEs: a conceptual and descriptive framework. New Product Development and Innovation Management, 2(3), 231-48.

[16]. Dionco-Adetayo, E. (2011). Guide to business research and thesis writing. Rasmed Publications Ltd, Ibadan

[17]. Dollinger, M.J. (1995). Entrepreneurship Strategies and Resources ( $1^{\text {st }}$ Ed). Flossmoor IL: Irwin/Austen Press

[18]. Doole, I. \& Lowe, R. (2004). International Marketing Strategy: Analysis, Development and Implementation. London: Thomson Learning.

[19]. Driscoll Angie M., Paliwoda Stanley J. (1997). Dimensionalizing International Market Entry Mode Choice, Journal of Marketing Management. 1997, 13, pp 57-87

[20]. Dunning, J. H. (1997). The European internal market programme and inbound foreign direct investment. JCMS: Journal of Common Market Studies, 35(2), 189-223.

[21]. Durmaz, A. Y., \& Tasdemir, A. (2014). A Theoretical Approach to the Methods Introduction to International Markets. International Journal of Business and Social Science, 5(6).

[22]. Erramilli M. Krishna, Agarwal S. and Dev Chekitan S. (2002). Choice between Non-Equity Entry Modes: An Organizational Capability Perspective, Journal of International Business Studies, 33(2), 223-242

[23]. Forsman, M., Hinttu, S. \& Kock, S. (2002), "Internationalization from a SME perspective", 18th Annual IMP Conference, Dijon, France.

[24]. Ghauri, P. N., \& Grønhaug, K. (2005). Research methods in business studies: A practical guide. Pearson Education.

[25]. Harrigan K. R. (1988). Joint Ventures And Competitive Strategy, Strategic Management Journal, 9, 141-158.

[26]. Hauck, D. (2010). Critical factors influencing export intensity: An explorative analysis of Mexican sporadic and regular exporting firms in the region of Puebla. Tesis Licenciatura. International Business Administration. Departamento de Administración de Negocios Internacionales, Escuela de Negocios y Economía, Universidad de las Américas Puebla.

[27]. Hollensen S. (2007). Global Marketing: A Decision-Oriented Approach, Pearson Education Limited, Edinburgh .

[28]. Ietto-Gillies, G. (2009). Conceptual issues behind the assessment of the degree of internationalization. Transnational Corporations, $18(3), 59-83$.

[29]. Jankowska, J. (2011). Measure of Company Internationalization. In A. Nalepka \& A. Ujwary-Gil (Eds.), Business and Non-profit Organizations facing increased competition and growing customers' demands. Retrieved from https://books.google.com/books?isbn=8388421794

[30]. Johanson, J \& Vahlne, J. (1977). The internationalization process of the firm: A model of knowledge development and increasing foreign market commitments. Journal of International Business Studies, 8(1), 23-32.

[31]. Johanson, J. \& Wiedersheim-Paul, F. (1975). The Internationalization of the Firm - Four Swedish Cases. International Marketing Review, 12(3), 305-322.

[32]. Kotabe Masaaki, Helsen Kristiaan (2010). Global Marketing Management, John Wiley \& Sons, Inc.,USA

[33]. Lafontaine Francine (1993) Contractual Arrangements as Signaling Devices: Evidence from Franchising, Journal of Law, Economics, \& Organization, Vol. 9, No. 2 (Oct., 1993), pp. 256-289

[34]. Lambin Jean-Jacques, (2007). Market-Driven Management, Palgrave Macmillan, Retrieved from http://www.palgrave.com/business/lambin/students/pdfs/note\%2013.pdf

[35]. Lloyd-Reason, L. (2003). Competing in global markets: Internationalisation strategies of small and medium sized enterprises in central and eastern Europe, Fifth International Conference on "Enterprise in Transition" pp635-651.

[36]. Manolova, T.S., Brush, G., Edelman, F. \& Greene, G. (2002). Internationalization of small firms. International Small Business Journal, 20 (1), 9-31.

[37]. Masum, M. \& Fernandez, A. (2008). Internationalization process of SMEs: Strategies and methods, Vasteras, Sweden. Retrieved from http://mdh.divaportal.org/smash/record.jsf?pid=diva2:121500

[38]. Matenge, T. (2011) Small Firm Internationalization - A Developing Country Perspective. International Journal of Business Administration, 2(4), 103-111.

[39]. McAuley, A. (1999). Entrepreneurial instant exporters in the Scottish arts and crafts sector. Journal of International Marketing, 7(4), 67-82.

[40]. Ministry of Finance, Planning and Economic Development (2008). Enhancing the Competitiveness of Micro, Small and Medium Enterprise (MSMEs) in Uganda: Two Picture of Ugandans engaged in Small business trade activities and food industry. Discussion Paper 15.

[41]. Ogbuehi, A.O. \& Longfellow, T.A. (1994). Perceptions of U.S. manufacturing SMEs concerning exporting: A comparison based on export experience. Journal of Small Business Management, 37-47.

[42]. Osunsan, O. K. (2015). Gender and Performance of Small Scale Enterprises in Kampala, Uganda. Asian Journal of Social Sciences \& Humanities Vol, $4,1$.

[43]. Patel, C.P. \& D’Souza, R.R. (2009). Leveraging Entrepreneurial Orientation to Enhance SME Export Performance. An Office of Advocacy Working Paper, 337, 29. 
[44]. Peng, M. W. \& Delios, A. (2006). What determines the scope of the firm over time and around the world? An Asia Pacific perspective. Asia Pacific Journal of Management, 23, 385-405.

[45]. Pollard, D. (2001). The Internationalization of SMEs in transformation economies: A research blackhole?, International conference on Enterprise in transition, 2744-2759

[46]. Rocco, T. S., Bliss, L. A., Gallagher, S., \& Pérez-Prado, A. (2003). Taking the next step: Mixed methods research in organizational systems.Information Technology, Learning, and Performance Journal, 21(1), 19.

[47]. Root, F. R. (1994). Entry strategies for international markets. Jossey-Bass.

[48]. Rowden, R.W. (2001). Research Note: How a Small Business Enters the International Market. Thunderbird International Business Review, 43(2), 257-268.

[49]. Rutashobya, L. \& Jaensson, J.E. (2004). Small Firm's Internationalization for Development in Tanzania: Exploring the Network Phenomenon. International Journal of Social Economics, pp. 159-72. Retrieved from http://dx.doi.org/10.1108/03068290410515484

[50]. Sapienza, H. J., E. Autio, \& S. Zahra. (2003). Effects of Internationalisation on Young Firms' Prospects for Survival and Growth, paper presented at the Academy of Management Meeting,

[51]. Sim, A. B., \& Pandian, J. R. (2003). Emerging Asian MNEs and their internationalization strategies - Case study evidence on Taiwanese and Singaporean firms. Asia Pacific Journal of Management, 20(1), 27-50.

[52]. Singh, G., Pathak, R.D. \&Naz, R. (2010). Issues Faced by SMEs in the Internationalization Process: Results from Fiji and Samoa. International Journal of Emerging Markets, 5 (2), 153-181.

[53]. Sooreea Rajeev, Sharma Supriya and Luong Lina (2012). The Globalization Of Northern California's Biotechnology Industry, Journal of International Business Research, Volume 11, Special Issue, Number 3, 2012

[54]. Sullivan, D. (1994). Measuring the degree of internationalization of a firm. Journal of International Business Studies, $2,325-342$.

[55]. Tesfayohannes, M. (2012) "African Entrepreneurs Should Plan and Aspire Beyond the Fence at the Current Complex Global Business Environment.” European African Alliance Conference 2012: Development Initiatives, Trade Relations and Interregional Cultural Exchange in the European African Alliance, Berlin, Germany.

[56]. Thompson A. A., Strickland A. J. and Gamble J. E. (2010). Crafting and Execution Strategy: The Quest for Competitive Advantage, Concepts and Cases, The McGraw-Hill Companies, Inc, New York, NY. 10020.

[57]. Ural, T. \& Acaravci, S.K. (2006). The Effects of Firm's Strategic Factors on Export and Firm Performance: A Comparison of Permanent and Sporadic Exporters. Problems and Perspectives in Management, 4(4), 41-62.

[58]. Vida, I., Reardon, J., \& Fairhurst, A. (2000). Determinants of international retail involvement: The case of large U.S. retail chains. Journal of International Marketing, 8 (4), 37-60.

[59]. Welch, L.S. \& Luostarinen, R.K. (1988). Internationalization: Evolution of a Concept. Journal of General Management, 14 (2) 3664.

[60]. Wright, M., Westhead, P. \& Ucbasaran, D. (2007). Internationalization of small and medium sized enterprises (SMEs) and international entrepreneurship: a critique and policy implications. Regional Studies, 41, 1013-1029.

[61]. Wu, D., \& Zhao, F. (2007). Entry modes for international markets: Case study of Huawei, a Chinese technology enterprise. International review of business Research papers, 3(1), 183-196.

[62]. Zain, M., \& Ng, S.I. (2006). The Impacts of Network Relationships on SMEs Internationalization Process. Thunderbird International Business Review, 48(2), 183-205.

[63]. Zizah, C. S. (2010) Models, Processes, and Factors influencing Internationalization: The case of Malaysian SMEs, Unpublished PhD Thesis, Murdoch University. 